\title{
The University of Iowa Libraries' Undergraduate User Needs Assessment
}

\section{Leo Clougherty, John Forys, Toby Lyles, Dorothy Persson, Christine Walters, and Carlette Washington-Hoagland}

\begin{abstract}
The university community is not a static environment but, rather, one fraught with change and adjustment to change. How do academic libraries within a university setting effectively address the evolving service and resource needs of a diverse patron community? One method that has received increasing attention is the development and implementation of internal instruments specifically designed to assess user satisfaction with services and resources. This study assesses undergraduate resource and service needs, identifies librarywide unmet needs, and gives both library user and librarian an opportunity to engage in proactive dialogue.
\end{abstract}

Key to the success of any academic program is the quality of its library system. The University of Iowa Libraries' main function is threefold: to serve as a base of operation for access to information and resources, to function as a resource tool for faculty in the development and delivery of instructional programs specifically designed to enhance course development, and to support academic research. The University of Iowa's library system serves approximately 28,000 undergraduate and graduate students and 1,700 faculty and instructors.

The library system consists of the Main Library and eleven specialized branch li- braries: Art Library, Biological Sciences Library, Chemistry/Botany Library, Engineering Library, Geology Library, Hardin Library for the Health Sciences, Marvin A. Pomerantz Business Library, Mathematical Sciences Library, Physics Library, Psychology Library, and the Rita Benton Music Library. It is the largest library system in Iowa and contains more than 3.8 million volumes.

\section{Utility of Study}

Central to the University of Iowa Libraries' mission is a commitment to create a learning environment that encourages quality research and scholastic achieve-

Leo Clougherty is Head of the Chemistry/Botany Libraries at the University of Iowa; e-mail: leoclougherty@uiowa.edu. John Forys is Head of the Engineering Library at the University of Iowa; e-mail: john-forys@uiowa.edu. Toby Lyles is Minority Research Librarian in the University of Iowa Libraries; $e$ mail: toby-lyles@uiowa.edu. Dorothy Persson is Head of the Psychology and Physics Libraries at the University of Iowa; e-mail: dorothy-persson@uiowa.edu. Christine Walters is Reference Assistant in the University of Iowa Libraries; e-mail: christine-walters@uiowa.edu. Carlette Washington-Hoagland is Assistant to the University Librarian/Special Project Coordinator in the University of Iowa Libraries; $e$ mail: carlette-w-hoagland@uiowa.edu. 
ment in a diverse university community. One of the major initiatives developed to address this goal was the creation of The User Needs Assessment Project. More specifically, this project was developed to assess library user satisfaction with current information services and resources, to help identify librarywide user service and resource needs, and to increase dialogue and involvement with library users.

\section{Because the undergraduate user category represents the libraries' largest patron base, it was chosen as the first to assess.}

A second User Needs Assessment Group was appointed by the University of Iowa Libraries' Executive Council in 1996. An analysis of current literature on library needs assessment tools and strategies aided the development and implementation of a pilot project that same year. As a result, both an implementation timetable and a three-step plan to assess the libraries' internal user community (undergraduate, graduate, faculty, and staff) was developed. Because the undergraduate user category represents the libraries' largest patron base, it was chosen as the first to assess. A pilot survey was administered in class to 138 Rhetoric II students (Iowa's equivalent of freshmen English) during the fall semester of 1996 . The findings of the pilot project underscored the need to conduct a more broad-based analysis.

The second User Needs Assessment Group was established in May 1997. This working group was assigned the task of developing and conducting a more comprehensive study of the undergraduate user group. The objectives of the Undergraduate User Needs Assessment Survey were:

- to learn how undergraduates access library resources and services;

- to learn what library services, resources, and facilities undergraduates use for study and research;

- to identify undergraduate perceptions of library resources;
- to learn how satisfied undergraduates are with library resources and services;

- to identify undergraduate unmet needs.

\section{Literature Review}

Librarians have an ongoing interest in the measurement and improvement of public services and in understanding the information search process. The concept of the undergraduate library has shifted from that of a place where large numbers of students are eased into intellectual life, nurtured by a large staff of professionals physically present to assist in the completion of assignments such as lengthy term papers, to one where students can successfully navigate independently at times convenient to them, twenty-four hours a day, seven days a week, with staff not physically present, but with guidance and advice from professionals still made available with the help of new technology. ${ }^{1}$

In addition, librarians have received new challenges from institutions such as the Carnegie Foundation for the Advancement of Teaching urging that the academic library fulfill its potential as a "salon" for the setting of intellectual values, be a "permanent exhibit of the powers and benefits of information literacy," an "information smorgasbord," a "window," a "watch-tower," and a "multimedia kiosk."

Richard M. Dougherty discussed a technical transformation in which researchers will attach more importance to locating and obtaining information, and less importance to where the information originated. He added that library services need to accommodate the actual abilities of scholars to locate and retrieve library materials. $^{3}$

\section{User Surveys}

As is common in libraries and reflected in the large body of literature, the survey, the standard method of research, is used widely to assess undergraduate perceptions of service ${ }^{4}$; but many innovative methods have been added to improve quality and accuracy, notably focus groups ${ }^{5}$ and electronic surveys. ${ }^{6}$ Some 
deal only with undergraduates, whereas others use one general survey for library users of differing status within the university community, including undergraduates. Current research indicates that user surveys have two main functions: (1) to gauge the users' perception of current library resources and services, and (2) to gauge the future needs of library users. User studies should be repeated regularly. They become essential when (1) a library has gone through significant change and needs to assess how it affects users' views of service, or (2) significant changes are contemplated and user input and support are critical. ${ }^{7}$

There are many reports on general undergraduate library user surveys conducted at large institutions. Some deal only with undergraduates, others use one general survey for library users of differing status within the university community, including undergraduates. Still others create segmented surveys for faculty, staff, and graduate and undergraduate students, all under the umbrella of one library user survey. ${ }^{8}$

The University of Michigan believed that library users should be involved in decisions about the functions of public service. ${ }^{9}$ Therefore, the university conducted a library user survey of graduate and undergraduate students and faculty. Research was conducted to respond to accountability demands, encouragement to adopt total quality management and just-in-time concepts, the need for user training in new electronic sources, adjustments to a growing diverse population, and the need to reallocate resources in the library. During a year-long study, the User Study Committee identified areas critical for user input. The committee worked with nine focus groups and conducted a telephone survey from a random sample of library users. The results indicated that the following areas required further study: access to materials, library communication with patrons, and staffing arrangements. ${ }^{10}$

A survey at Duke University was initiated in an attempt to assist long-range planning efforts by determining user needs. A marketing research firm was chosen to conduct the study to avoid bias. The study involved focus groups and mailed surveys sent to the university community of faculty, staff, and graduate and undergraduate students. ${ }^{11}$ The second half of the survey desired usage "focused on the perceptions of the future, or ideal, structure for information retrieval, sometimes based in a library, sometimes not." After ideas were gathered, respondents were asked what current library programs they would be willing to eliminate to achieve the ideal library. ${ }^{12}$

A number of other user studies have been developed for a variety of reasons, ranging from administrative reaction to scarce funding ${ }^{13}$ and developing instruments to identify patron-specific needs, ${ }^{14,15}$ to assessing the impact of cooperative relationships between faculty and librarians. ${ }^{16}$

A group at the University of Toronto studied use of the online public access catalog and of the university Web site by people telnetting into UTLink. They investigated who used the Internet (men versus women), why they used it, what type of information they needed, and how they intended to use the information they found. The research also involved participation by student-run focus groups used to elicit additional suggestions. Student facilitators prepared a written report, and one of the researchers reviewed the videotaped focus group sessions. ${ }^{17}$

\section{How Undergraduates Use the Library}

A further review of the literature reflects efforts made by small and large libraries to devise ways of not only measuring how undergraduates use specific services provided by the library, ${ }^{18}$ but also assessing the psychological processes of information use, along with study on the changes in use patterns. ${ }^{19}$ Carol C. Kuhlthau studied not only the "cognitive aspects of information seeking," but also examined the feelings of uncertainty and anxiety users commonly experience when gathering information. She believes that uncertainty can be anticipated and that 
librarians can improve user success by providing appropriate assistance. ${ }^{20}$

A study by Barbara Fister concluded that faculty play a large role in guiding the research of their students. She noted that using finding tools may be a good starting point for the preliminary phase of the research process; later phases force students to rely more on citations as the research questions are more clearly defined. ${ }^{21}$

There has been a shift in importance from input measures (collection size) to output measures (performance standards) $)^{22}$ and efforts to reliably measure elusive concepts such as library impact on users. Danuta A. Nitecki explored the transferability of an assessment tool developed by marketing researchers to measure service quality for use with library users. The survey instrument measured the dimension of service by asking respondents to allocate points among different library services. ${ }^{23}$

\section{Refinements}

The problem always encountered when conducting a survey of service quality is the difficulty in involving a significant number of undergraduates in the process. Many studies reveal problems in gathering a statistically significant, unbiased sample. ${ }^{24}$ Additional efforts involving telephone interviews to pretest questions, ${ }^{25}$ interviews with groups and individuals, ${ }^{26}$ public forums, ${ }^{27}$ and diaries ${ }^{28}$ or a combination of mailed surveys and survey administration in classes have been used to compensate for these problems. Awareness of, and satisfaction with, services may be perceived differently among users so that survey results may be inconclusive, making it less likely the research will have an impact. Doris J. Schlichter and J. Michael Pemberton concluded that pretesting survey questions is necessary so that respondents are choosing among clearly delineated areas of concern. ${ }^{29}$

\section{Methodology}

A literature review on user needs assessment processes and tools supported the group's decision to develop a mailed survey. Based on the pilot project results, the original survey was redesigned to better address each of the project objectives.

The first step in the redesign process was a thorough evaluation and redesign of the pilot survey. Close attention was paid to question order, defining commonly used library terminology, scaling, incorporating qualitative measures (open-ended questions), and formatting. As a second step, the eleven branch library unit heads and the department heads in the public service units of the Main Library were given the opportunity to review the pilot survey and forward suggestions regarding additional inclusions. Next, the project's statistical consultant, the university registrar and an editor reviewed the survey to identify any scaling or design problems and to check for sufficient instructions, grammatical accuracy, readability, and consistency. The final undergraduate survey design consisted of seventy-eight forced-choice questions, three open-ended questions, and six demographic questions.

\section{Pretest}

Current research supported the group's decision to use a focus group format for pretesting the survey. The registrar compiled a random list of undergraduates, and project members solicited participation by telephone.

A professional consultant from the University of Iowa Office of Management and Business Development facilitated group discussion. After completing the survey, participants engaged in open dialogue with the consultant about each of the survey's questions and sections. Pretest results pinpointed design flaws related to library jargon and question order, which then were corrected.

\section{Sampling}

The study population consisted of the entire undergraduate student body ( $\mathrm{n}=$ $17,908)$ enrolled during the fall semester 1997, with two exceptions. Special enrollment students (A9) were excluded from 
the sample. The A9 classification includes students taking special courses, but not officially enrolled in a degree-granting program. Students who requested that their address be kept confidential also were excluded from the sample.

A stratified random sample of approximately 10 percent $(n=1,790)$ of the undergraduate population was drawn by the registrar's office. The study population was stratified by class level (freshman, sophomore, junior, and senior) and college (Liberal Arts, Engineering, Nursing, and Business).

\section{Initial and Follow-up Mailings}

The initial mailing generated a 20 percent response rate. Two additional mailings resulted in a total response rate of 39.5 percent, or 707 returned surveys, of which 656 were usable.

\section{Data Coding and Analysis}

Staff in the University of Iowa Data Entry Department coded the survey data with the exception of the three openended responses. The open-ended responses were coded and analyzed by the group. The survey data from the forcedchoice questions were compiled and analyzed by staff at the University of Iowa Evaluation and Examination Services and the statistical consultant.

\section{Findings}

The survey was divided into five sections: Section I: General Questions about the University of Iowa Libraries; Section II: Main Library Departments; Section III: Library Services and Departments; Section IV: Overall User Satisfaction; and Section V: Demographics. In Sections I through III, the use categories "very frequently," "frequently," and "sometimes" have been collapsed. The "seldom" response rate is sometimes large and may have a cumulative impact on the use of services or resources; however, its impact on decision-making is different than the other use categories mentioned. Therefore, the "seldom" and "never" categories are considered separately. In Section
IV, the satisfaction categories "very satisfied," "satisfied," and "somewhat satisfied" also have been collapsed. The "never used" category is not considered.

\section{Section I: General Questions about the University of lowa Libraries}

Library Usage: The results of this study revealed that a majority of respondents use the Main Library (86\%). Less than 50 percent of the respondents use any other library, even when one includes the "seldom" use category.

Purpose of Library Use: The top reasons cited by respondents for using the libraries were to study $(72 \%)$, to use the photocopiers $(70 \%)$ and to check out or borrow books, magazines, and journals (68\%). Students also frequently come to the library to use the instructional technology clusters $(60 \%)$. Only 18 percent of those surveyed come to the library to recall a book from another patron. Large numbers of respondents seldom check out items (24\%) and/or recall items (28\%).

Queries about Library Resources and Services: To answer questions about the libraries, 70 percent of the respondents seek assistance from library personnel and 56 percent ask another student for help. Only 31 percent of the respondents use printed handouts, 20 percent use Library Explorer (an electronic Web-based library tutorial), and nine percent use LWIS ( $\mathrm{Li}$ braries-Wide Information System, the libraries' Web page). A number of respondents categorized their use of these methods for seeking assistance in these areas as "seldom." For three of these methods (printed handouts-29\%, Library Explorer-19\%, and LWIS-16\%), more undergraduates selected "seldom" than "very frequently," "frequently," or "sometimes." Twentyfive percent of those surveyed "seldom" ask another student, and 19 percent "seldom" ask a library staff member.

Library Services: Seventy percent of the respondents reported that they use the libraries' public service desks (reference, 
circulation, information, and/or help desk). Small numbers of those surveyed participate in reference consultations (7\%) or attend library instructional classes (3\%).

Library Resources: Sixty-six percent of those surveyed reported use of the libraries' catalogs (computerized and print), 40 percent use newspapers, and 33 percent use the computers in the information commons and information arcade. Less than 30 percent use printed handouts $(27 \%)$, printed indexes and bibliographies $(22 \%)$, microfilm and microfiche $(20 \%)$, CD-ROM databases (18\%), videos (17\%), or maps $(10 \%)$. In this section, more respondents chose "seldom" than "very frequently," "frequently" or "sometimes" for all of the resources except newspapers and card catalog. The response rate for "never" was more than 40 percent for every resource except the card catalog and newspapers.

\section{Section II: Main Library Departments}

Within the Main Library, 54 percent of those surveyed use the reference/information desk, 49 percent use access services, 32 percent use the information arcade, and 30 percent use media services. Other Main Library units receive little use. The response rate for "never" was more than 40 percent for every department except access services $(26 \%)$ and reference/information desk (20\%).

\section{Section III: Library Services and Departments}

Use of Reference Services: To obtain reference assistance, 56 percent of the respondents asked a library staff member in person, 19 percent asked for help via telephone, and six percent asked for assistance via e-mail. Large numbers of the respondents never use e-mail $(87 \%)$ or the telephone $(58 \%)$ to get reference assistance.

Use of Circulation Services: To obtain assistance with circulation services, 45 percent of the respondents asked a library staff member in person, 18 percent asked by telephone, and only ten percent used e-mail. Again, many of the respondents never use e-mail $(81 \%)$ or the telephone $(69 \%)$ to access these services.

Access to LWIS: Less than 50 percent of the respondents reported ever using LWIS. Eighty percent never use LWIS from outside the library, and 73 percent never use it from within the library. Only 15 percent reported using LWIS from inside the libraries, whereas ten percent use it from outside the libraries.

Web Browsers: Netscape (83\%) is the most widely used Web browser. Forty-three percent of the respondents indicated that they use Microsoft Internet Explorer "very frequently," "frequently," or "sometimes." Not many of the respondents use LYNX (8\%), Mosaic (4\%), or another browser (19\%).

Access to OASIS: The majority of respondents reported that they access OASIS (Online Access System for Information Sources) from within a library $(71 \%)$ rather than from outside (36\%). Forty-five percent reported never accessing OASIS from outside a library, whereas only 14 percent reported never accessing OASIS from within a library.

Use of OASIS: Respondents use the LCAT (online catalog of books and other material owned by the University of Iowa) section of OASIS most (77\%). But 61 percent of the respondents reported that they use the indexes section of OASIS to find citations to magazines and journal articles. Fifty-one percent reported never using LIBCATS (Library Catalogs, online catalogs of material owned by other libraries).

\section{Section IV: Overall User Satisfaction}

In calculating user satisfaction, "very satisfied," "satisfied," and "somewhat satisfied" were collapsed into one percentage. Also, "n" (sample size) based on the respondents who reported actually using each resource or service was used. This approach reflected the level of satisfaction 
of only those who reported using the resource or service.

Resources: The respondents are satisfied with the libraries' resources. Satisfaction ranged from a low of 89 percent for the card catalog (print) to a high of 95 percent for printed handouts. However, most respondents indicated that they "never" use LWIS (71\%), Library Explorer (64\%), and CD-ROM databases (63\%). Another important finding is that the maximum number of those surveyed who were very dissatisfied with any of the resources used at the libraries was only three percent.

Services: Of those respondents who used the services, 97 percent were satisfied with the services provided at the public service desks. This is very high, especially because 85 percent of the respondents have used them. Ninety-four percent were also satisfied with reference consultations. Instructional classes satisfied 88 percent of the respondents who attended them. However, most respondents "never" used reference consultations $(86 \%)$ or participated in instructional classes $(84 \%)$.

Undergraduate Perceptions of Library Resources and Services: Much of what was found in overall satisfaction is reflected in these results as well. Most of those surveyed agree that the libraries offer the services they need $(79 \%)$, the libraries' staff is helpful $(77 \%)$, the libraries' staff is courteous $(70 \%)$, the libraries do a good job meeting their needs overall (66\%), and the libraries have sufficient resources and materials (66\%). Respondents expressed lower levels of agreement regarding the libraries' pleasant physical facilities (50\%) and their ability to easily locate the materials they need (49\%). The "undecided" category ranged only between 13 percent for offering the services they need and 23 percent for ease in locating materials. The respondents most disagreed with "Libraries have pleasant physical facilities" (30\%) and "Overall, I can easily locate the materials I need" (28\%).

\begin{tabular}{|c|c|c|c|c|}
\hline \multicolumn{5}{|c|}{$\begin{array}{c}\text { TABLE } 1 \\
\begin{array}{c}\text { Descriptive Statistics, Comparison } \\
\text { with Registrar's Data }\end{array} \\
\end{array}$} \\
\hline & \multicolumn{2}{|c|}{ Survey Data } & \multicolumn{2}{|c|}{ Registrar's Data } \\
\hline Variable & $\mathrm{N}$ & $\%$ & $\mathrm{~N}$ & $\%$ \\
\hline \multicolumn{5}{|c|}{ Class Level } \\
\hline Freshmen & 102 & 16 & 4,935 & 28 \\
\hline Sophomores & 132 & 20 & 4,010 & 22 \\
\hline Juniors & 181 & 28 & 4,417 & 25 \\
\hline Seniors & 240 & 37 & 4,546 & 25 \\
\hline \multicolumn{5}{|c|}{ Sex } \\
\hline Male & 234 & 36 & 8,609 & 46 \\
\hline Female & 422 & 64 & 10,145 & 54 \\
\hline \multicolumn{5}{|c|}{ Age } \\
\hline $18 \&$ under & 60 & 9 & 2,475 & 13 \\
\hline $19-21$ & 390 & 59 & 10,289 & 55 \\
\hline $22-23$ & 122 & 19 & 3,320 & 18 \\
\hline $24 \&$ over & 83 & 13 & 2,670 & 14 \\
\hline \multicolumn{5}{|c|}{ Housing } \\
\hline University & 170 & 26 & 5,737 & 21 \\
\hline Off Campus & 486 & 74 & 22,134 & 79 \\
\hline \multicolumn{5}{|c|}{ Enrollment } \\
\hline Part Time & 66 & 10 & 2,520 & 13 \\
\hline Full Time & 589 & 90 & 16,234 & 87 \\
\hline \multicolumn{5}{|c|}{ College } \\
\hline Liberal Arts & 494 & 76 & 15,243 & 85.1 \\
\hline Business & 81 & 12 & 1,095 & 6.1 \\
\hline Engineering & 46 & 7 & 1,147 & 6.4 \\
\hline Nursing & 26 & 4 & 423 & 2.4 \\
\hline Uncertain & 6 & 1 & 0 & 0.0 \\
\hline
\end{tabular}

\section{Section V: Demographics}

Class Level: The percentage of responses increased directly with class level; freshmen were the lowest percentage of the respondents $(16 \%)$ and seniors the highest (37\%). Of the freshmen (493) surveyed, only 21 percent responded. Thirty-three percent of the sophomores (401), 41 percent of the juniors (442), and 53 percent of the seniors (454) responded.

Sex: Sixty-four percent of the respondents were female. 
Age: Most of the respondents were between 19 and 23 years old (78\%).

Housing: Most of the respondents lived off-campus (74\%).

Enrollment: Ninety percent of the respondents were full-time students.

The largest number of responses (18\%) expressed dissatisfaction with OASIS, the primary concern being the need to update or replace the current OASIS system.

College: Although 76 percent (494 of 653) of the responses came from the liberal arts/education students, only 32 percent of these students in the sample (494 of $1,524)$ replied to the survey. Of the 114 engineering students surveyed, only 40 percent responded to the survey. Of the 43 nursing students in the sample, 60 percent responded. Of the 109 business students surveyed, 74 percent responded. The study demographics very closely matched those of the university (see table 1$).^{30}$

\section{Content Analysis of Open-Ended Questions}

The results of the three qualitative measures are described below. Each openended response was coded separately. Like responses were grouped together, and a percentage was determined based on the total number of undergraduates who responded to each of the respective questions.

\section{Comments or Suggestions about Library}

Resources: One hundred and seventy comments were received in response to this question, and they were concentrated in four areas. The largest number of responses $(18 \%)$ expressed dissatisfaction with OASIS, the primary concern being the need to update or replace the current OASIS system. Another 18 percent expressed frustration with the difficulty they encountered in locating library materials. A smaller number (13\%) expressed a lack of awareness of available library resources and/or a need for more information and/or instruction with regard to library resources. The need for additional or updated library computers and printers was voiced by 13 percent of the respondents.

\section{Comments or Suggestions about Library} Services: Most (54\%) of the eighty-four responses received about library services concerned library staff. Of the staff-related comments that could be termed either negative or positive, slightly more than half were negative. A need was expressed for more staff training. Twentyfive percent of the comments expressed the need for more publicity/awareness about library services and for more library instruction in various formats.

\section{General Comments or Suggestions on} How to Improve Library Services: This question generated 438 identifiable comments or suggestions. Of these, the overwhelming majority (93\%) dealt with some aspect of the physical facilities, collections, or staff. The area of most concern to 51 percent of the respondents was that of physical facilities, with 28 percent noting the need to refurnish and remodel the Main Library. The need to purchase chairs in the Main Library was specifically mentioned by 10 percent of respondents. Eight percent expressed the need for additional or updated computers, printers, copiers, and network access.

As for collections, 27 percent of the respondents expressed some degree of frustration in locating or gaining access to library materials. These comments included the need to reshelve and process materials more quickly; difficulty in understanding the physical arrangement of materials; dealing with misshelved, missing, or mutilated materials; the need for more signage; and the need to update and expand the collection.

Staff-related comments comprised 15 percent of responses to this question and tended to be more negative than positive by a margin of nearly three to one. The need was expressed for additional staff 
TABLE 2

Significant Chi-Square at the $\mathbf{. 1 0}$ level

$\begin{array}{lllll}\text { Class } & & \text { Enrol- } \\ \text { Level Sex Age Housing } & \text { lment College }\end{array}$

The University of Iowa has 11 departmental libraries, and one Main Library, how frequently do you use any of the following:
8. Main Library
$* * \quad * * \quad * 0.002$
**
$0.001 * 0.002$

How frequently do you use any of the above libraries to:

13. Study

14. Check out/borrow books,

$\begin{array}{rrrrrr}* * & * * & 0.034 & 0.001 & 0.024 & * * \\ 0.002 & 0.092 & * * & 0.001 & * * & * * \\ & & & & & \\ 0.001 & 0.001 & 0.017 & 0.001 & * * & * * \\ * * & * * & 0.001 & * * & 0.001 & * 0.001\end{array}$

16. Use the photocopiers

17. Use the ITC $^{1}$

0.001

$* *$

To answer questions about any of the libraries, how frequently do you:

18. ask another student

19. use Printed Handouts

** $\quad 0.030 \quad 0.028 \quad * *$

20. use Library Explorer

21. use LWIS $^{2}$

22. ask a library staff member

** 0.002

** 0.037

$* *$

$* *$

** $\quad * *$

$* *$

** $\quad 0.001$

0.055

$\begin{array}{rrr}* * & * * \\ * * & * * \\ * * & * * \\ 0.001 & * * \\ * * & * *\end{array}$

How frequently do you use the following services at any of the libraries:

24. Reference consultation ${ }^{3}$

$* * \quad * * \quad * * \quad * *$

$0.006 \quad * *$

How frequently do you use:

26. Printed handouts

27. Videos

28. Microfilm or microfiche

29. CD-ROM databases

30. Newspapers

32. Computers in the Information

$$
\begin{array}{r}
0.012 \\
* \\
* * \\
0.067 \\
* * \\
\text { de }
\end{array}
$$

to develop presentations, web pages, or scan material

34. Maps

0.076

0.030

0.017

$* *$

$* *$

0.077

0.067

** $\quad 0.012$

$* *$

0.006

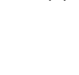

To get assistance in any of the libraries (reference services), how frequently do you:

44. Use the telephone to call

$0.097 \quad 0.014$

0.021

0.005

0.018

$* 0.061$ a library

45. Speak to a library staff member in person

and better training for library personnel.

\section{Future Implications and Concluding Comments \\ Content Analysis:}

The area of most concern to respondents was that of the physical facilities of the Main Library. Although some concern was expressed about the physical condi- tion of the branch libraries, the Main Library was the overwhelming focus. These undergraduates expressed a clear belief that the Main Library is in need of being remodeled and refurbished. The Main Library was built in 1951, and over a period of eleven years (1961-1972), it underwent three new additions.

Next, the respondents expressed frustration at not being able to locate needed 
TABLE 2 (cont.)

Significant Chi-Square at the .10 level

\begin{tabular}{llllll}
\hline \hline Class & & \multicolumn{3}{c}{ Enrol- } \\
Level & Sex Age Housing lment College \\
\hline
\end{tabular}

To renew, recall, check on items you have checked out, or check on the status of other items (circulation services) in any of the libraries, how frequently do you:
47. Use the telephone
$* *$
0.088
0.004
0.008
$* *$
48. Speak to a library staff
member in person

How frequently do you use the following World Wide Web browsers:
51. Netscape
** $\quad * * \quad 0.001$
$* * \quad 0.003 \quad * 0.003$

How frequently do you access the libraries' computerized catalogues and indexes (OASIS):

56. From within one of the $\quad \begin{array}{llllll}* * & 0.074 & 0.025 & 0.028 & 0.001 & * 0.001\end{array}$ libraries?

When you use OASIS, how frequently do you use the following:
58. $\mathrm{LCAT}^{4}$
** $\quad 0.055 \quad 0.015$
** $\quad 0.005 * 0.001$

Please indicate if you are: 1-Very Satisfied, 2-Satisfied, 3-Somewhat Satisfied, 4-Dissatisfied, or 5-Very Dissatisfied with the following library resources and services:
61. Printed handouts
63. LWIS $^{3}$
66. OASIS $^{5}$
68. Multimedia stations in the
$* * * 0.050$
** $\quad * *$
$* * * 0.030$
$* *$
$* * * 0.044$
$* *$
$* *$
$* *$
$* *$
$* 0.044$
$\begin{array}{rr}* * & * * \\ * * & * 0.031 \\ * * & * * \\ * * & * *\end{array}$
70. Reference consultation ${ }^{2}$
$* * * 0.063$
$* * * 0.097$
$* * \quad * 0.044$
$* * \quad * *$
71. Public service desk

Please indicate if you 1-Strongly Agree, 2-Agree, 3-Undecided, 4-Disagree or 5-Strongly Disagree with the following statements:
75. The libraries' staff is helpfu
0.028
** $\quad 0.003$
$* *$
0.0310 .092
$\begin{array}{lll}* * & * * & * * \\ * * & * * & * *\end{array}$
78. The libraries have pleasant
0.001
** $\quad 0.001$
$0.012 \quad 0.001$ physical facilities

79. Overall, I can easily locate the materials I need

** $\quad 0.006 \quad 0.086$

** $\quad 0.032$

$* *$

* Chi-square is significant, but not a valid measure.

* Chi-square is not significant.

1. Instruction Technology Cluster

2. The libraries' Web page

3. Reference by appointment

4. To find University of Iowa books and other materials

5. Libraries' Comp Computerized Catalogs and Indexes

library materials. This frustration appears to have a number of causes: the current physical arrangement of library stacks; missing, mutilated, or misshelved materials; and the library not owning materials listed in computerized indexes. They stated that there is a need to more quickly reshelve books and journals, expand and update the collection, and provide more and better signage. There is also the sense that the sheer size and complexity of the university libraries and their collections overwhelm some students. In addition, these students indicated that they were not fully aware of the full range of resources and services available to them. They expressed the need for more publicity about these resources. 
Although the respondents indicated a degree of satisfaction in their dealings with library personnel, they also indicated experiencing a certain number of negative encounters. They expressed some need for additional training, for part-time evening and weekend staff in particular, with regard to customer service and awareness of library resources and services.

\section{Overall Concluding Comments}

These conclusions are based on the results of a chi square test of significance in addition to a standard frequency distribution. All correlation measures with a probability of .10 or lower were considered significant (see table 2).

A balanced perspective was solicited using seventy-eight forced-choice and three open-ended questions. Forty-seven percent of the undergraduates did not write a comment, and data analysis of the close-ended questions show that the undergraduate students are satisfied overall with the libraries.

Fifty-three percent (53\%) of the undergraduate respondents did comment on one or more of the three open-ended questions. Content analysis of these questions along with data from the forcedchoice questions point to areas requiring attention-namely physical facilities, perceptions of library staff, staffing of service desks, and awareness of library services and resources. The data suggest that undergraduates prefer human contact and gravitate toward on-site use of library services and resources.

A profile of a "typical" undergraduate library user at the University of Iowa emerges from the data. The undergraduate is a 19- to 23-year-old female who uses the Main Library, in person, to study, make photocopies, and check out materials. She would be frustrated at times by her difficulty in finding resources. In addition, she would seek assistance from library staff, not technology, and would rarely, if ever, use any of the specialized resources or services in any of the libraries. The researchers are left wondering how this profile would change if more undergraduates 18 or under or 24 or over and male would have responded to the survey.

The respondents overwhelmingly use the Main Library, which houses the humanities and social sciences materials; the specialized branch libraries received much lower use. The data suggest that the university should concentrate its undergraduate efforts on services, collections, and facilities in the Main Library.

The responses to the open-ended questions demonstrate the respondents' knowledge and understanding of the libraries' fiscal situation. Even though these undergraduates desire some change, they realize that the lack of money slows progress.

The undergraduate is a 19- to 23year-old female who uses the Main Library, in person, to study, make photocopies, and check out materials.

The results of the survey identify where the libraries can concentrate their efforts for undergraduates. Undergraduate education presents challenges and opportunities for the library staff. Despite overall undergraduate satisfaction with the libraries, the survey pointed out areas requiring the staff's attention. Creativity, as well as additional monies and undergraduate input, will improve the University of Iowa Libraries' undergraduate services and resources.

\section{Recommendations}

A number of recommendations are suggested based on the results of this study. These include:

- improving the physical facilities of all eleven branch Libraries and in particular the Main Library;

- improving the perceptions of library staff;

- increasing the staffing of the public service desks;

- increasing public awareness of library services and resources;

- conducting additional follow-up analyses to address issues not captured by this survey. 


\section{Notes}

1. Mark Watson, Jody Bales Foote, and Roland C. Person, "Twenty Years of Undergraduate Libraries: Whence and Whither?" College and Undergraduate Libraries 3, no. 2 (1996): 11-25; Carla J. Stoffle, "A New Library for the New Undergraduate," Library Journal 115, no. 16 (Oct. 1990): $47-50$.

2. Major R. Owens, "The Academic Library and Education for Leadership," in Libraries and the Search for Academic Excellence: Proceedings of the Arden House Symposium, New York, March 1517, 1987 (Denver: Univ. of Colorado, 1987). Available as an ERIC document: ED 284-586.

3. Richard M. Dougherty, "Needed: User-Responsive Research Libraries," Library Journal 116, no. 1 (Jan. 1991): 59-62.

4. Sandra D. Hoffman and Anne-Marie Belanger, "Academic Libraries: The Students' View," Library Software Review 9, no. 4 (July-Aug. 1990): 232-33; N. A. Jacobs, "Students' Perceptions of the Library Service at the University of Sussex: Practical Quantitative and Qualitative Research in an Academic Library," Journal of Documentation 52, no. 2 (June 1996): 139-62; Kenneth W. Berger and Richard W. Hines, "What Does the User Really Want? The Library User Survey Project at Duke University," Journal of Academic Librarianship 20, nos. 5-6 (Nov. 1994): 306-9; Thomas Seay, Sheila Seaman, and David Cohen, "Measuring and Improving the Quality of Public Services: A Hybrid Approach," Library Trends 44, no. 3 (winter 1996): 464-90; Rosemary N. Chacha and Ann Irving, "An Experiment in Academic Library Performance Measurement," British Journal of Academic Librarianship 6, no. 1 (1991): 13-26.

5. Ellen Meltzer, Patricia Davitt Maughan, and Thomas K. Fry, “Undergraduate in Focus: Can Student Input Lead to New Directions in Planning Undergraduate Library Services?" Library Trends 44, no. 2 (fall 1995): 400-422; Margo Crist, Peggy Daub, and Barbara MacAdam, "User Studies: Reality Check and Future Perfect," Wilson Library Bulletin 68, no. 6 (Feb. 1994): 3841; Berger and Hines, "What Does the User Really Want?": Barbara Valentine, "Undergraduate Research Behavior: Using Focus Groups to Generate Theory," Journal of Academic Librarianship 19, no. 5 (Nov. 1993): 300-304; Mary Tygett, V. Lonnie Lawson, and Kathleen Weessies, "Using Undergraduate Marketing Students in an Unobtrusive Reference Evaluation," RQ 36, no. 2 (winter 1996): $270-76$.

6. Michel Dupagne, Frances Wilhoit, and Owen V. Johnson, "Faculty and Student Assessment of a Journalism Library," Journalism Educator 49, no. 3 (autumn 1994): 33-42; Watson, Foote, and Person, "Twenty Years of Undergraduate Libraries"; Keith G. Webster, The Use of IT in Library Evaluation: Electronic Surveying at the University of Newcastle, Available as an ERIC document: ED 405-878.

7. Crist, Daub, and MacAdam, "User Studies."

8. Kenneth W. Berger and Richard W. Hines, "What Does the User Really Want?"

9. Crist, Daub, and Mac Adam, "User Studies."

10. Ibid.

11. Berger and Hines, "What Does the Library User Really Want?" 306-9.

12. Ibid., 307-8.

13. James E. Prather and Michael L. Clemons, Results of a Survey of Pullen Library Users (Atlanta: Georgia State University Office of Institutional Planning, 1981). Available as an ERIC document: ED 206-318.

14. David C. Taylor, “Undergraduates' Use of Periodicals-Implications for Library Reference Work," Reference Librarian nos. 27-28 (1989): 51-65.

15. Jamshid Beheshti, "Beyond Circulation Statistics: Measuring Patterns of Book Use," Canadian Library Journal 46, no. 6 (Dec. 1989): 397-98.

16. Taylor, "Undergraduates' Use of Periodicals."

17. Joy Tillotson, Joan Cherry, and Marshall Clinton, "Internet Use through the University of Toronto Library: Demographics, Destinations, and Users' Reactions," Information Technology and Libraries 14, no. 3 (Sept. 1995): 190-98.

18. Hoffman and Belanger, "Academic Libraries"; Alice Omaji, "Non-Use of CD-ROM Databases in an Academic Environment," Computers in Libraries 14, no. 9 (Oct. 1994): 45-46; Valentine, "Undergraduate Research Behavior"; Barbara Fister, "The Research Processes of Undergraduate Students," Journal of Academic Librarianship 18, no. 3 (July 1992): 163-69; Dupagne, Wilhoit, and Johnson, "Faculty and Student Assessment of a Journalism Library"; Jacobs, "Students' Perceptions of the Library Service at the University of Sussex"; Beheshti, "Beyond Circulation Statistics."

19. Carol C. Kuhlthau, "Inside the Search Process: Information Seeking from the User's Perspective," Journal of the American Society for Information Science 42, no. 5 (June 1991): 361-71; Taylor, "Undergraduates' Use of Periodicals"; Dougherty, "Needed"; Watson, Foote, and Person, "Twenty Years of Undergraduate Libraries." 
20. Kuhlthau, "Inside the Search Process."

21. Fister, "The Research Processes of Undergraduate Students," 167-68.

22. Ronald R. Powell, "Impact Assessment of University Libraries: A Consideration of Issues and Research Methodologies," Library \& Information Science Research 14, no. 3 (July-Sept. 1992): $245-57$.

23. Danuta A. Nitecki, "Changing the Concept and Measure of Service Quality in Academic Libraries," Journal of Academic Librarianship 22, no. 3 (May 1996): 181-90.

24. Crist, Daub, and MacAdam, "User Studies"; Berger and Hines, "What Does the User Really Want?"; Dupagne, Wilhoit, and Johnson, "Faculty and Student Assessment of a Journalism Library."

25. Doris J. Schlichter and J. Michael Pemberton, "The Emperor's New Clothes? Problems of the User Survey as a Planning Tool in Academic Libraries," College and Research Libraries 53, no. 3 (May 1992): 257-65.

26. Fister, "The Research Processes of Undergraduate Students"; Chacha and Irving, "An Experiment in Academic Library Performance Measurement"; Tygett, Lawson, and Weessies, "Using Undergraduate Marketing Students in an Unobtrusive Reference Evaluation."

27. Pat Timberlake, Robert Heidlage, Nancy Myers, Paula Roper, and Marsha Stevenson, "Library Services to Undergraduates, Final Report July 18, 1989" (Columbia: Univ. of Missouri, 1989). Available as an ERIC document: ED 322-901.

28. Kuhlthau, "Inside the Search Process."

29. Schlichter and Pemberton, "The Emperor's New Clothes?"

30. A Profile of Students Enrolled at the University of Iowa Fall Semester 1997-98 (Iowa City: Univ. of Iowa, Office of the Registrar, 1997). 